\title{
HARE'S PREFERENCE UTILITARIANISM: AN OVERVIEW AND CRITIQUE
}

\author{
Mauro Cardoso Simöes ${ }^{l}$
}

\begin{abstract}
My purpose in this paper is to summarize some aspects of utilitarianism and to provide a general overview of Hare's preference utilitarianism, followed by a critique of Hare's preference theory.
\end{abstract}

KEYWORDS: Hare, Utilitarianism, Preferences, Critique.

\section{HARE'S PREFERENCE UTILITARIANISM - AN OVERVIEW}

Richard Hare is one of most foremost contemporary defenders of utilitarianism today. He is committed to the principle of utility - to the act which does more good, gives greater benefit, or which satisfies more preferences (desires), or the stronger of two or more preferences ${ }^{2}$. Hence we can classify him as a "preference utilitarian". Hare's moral theory is a very powerful one based on a synthesis of intuitionism and utilitarianism (although ultimately, intuitions are subordinate to utilitarian consideration in his theory) and is at present the most defensible form of utilitarianism.

\section{Preference Utilitarianism}

Hare maintains that there are two levels of moral thinking - the intuitive and the critical levels ${ }^{3}$. At the intuitive level, people apply moral intuitions or general prima facie principles (which they take for granted as given) to individual moral situations. These prima facie principles are derived by learning from others and in moral situations during our upbringing and

\footnotetext{
${ }^{1}$ Doutor em Filosofia pela Unicamp. Professor da Faculdade de Ciências Aplicadas da Unicamp. Email: mauro.simoes@fca.unicamp.br

${ }^{2}$ HARE, R. M. Moral Thinking. Its Levels, Method and Point. Oxford: Oxford University Press, 1981.

${ }^{3}$ Ibid., Chapters 2 and 3.
} 
past experiences and they are very deeply ingrained in us as feelings and dispositions ${ }^{4}$. However, intuitive moral thinking is not enough because moral conflicts may arise in cases where two or more intuitive prima facie principles have been learnt for applying to a "new" moral situation". Hence we must resort to critical moral thinking.

The process of a critical moral thinking involves the consideration of people's preferences and this is what makes Hare's moral theory utilitarian and consequentialistic $^{6}$. To Hare, the good is that which is subjectively preferred, desired or wanted. The action which satisfies the strongest preferences of people is the right action. This is slightly different from the traditional utilitarian principle that "the rightness or wrongness of actions and/or moral rules should be evaluated solely in terms of theirs consequences for all concerned" (that is, in terms of their ability "to maximize the good, happiness or benefit to people").

Hare's brand of utilitarianism arose as a response to the criticism put forward against the traditional utilitarian theories by Jeremy Bentham, John Stuart Mill, G.E. Moore and other $18^{\text {th }}$ and $19^{\text {th }}$ century utilitarians. Let us examines briefly the characteristics of the main traditional forms of utilitarianism and act and rule utilitarianism - and the objections advanced against them.

\section{Hedonistic UTILITARIANISM}

Hedonistic utilitarianism was first formally introduced by Jeremy Bentham who was disenchanted with the existing legal and social institutions of England and the prevalent legal theory of this time ${ }^{7}$. The moral theory during his time was based on the theory of introspection or intuitionism. It was believed that there were certain clearly recognizable "natural laws" engraved by God in the human mind and all we had to do to discover if an act was right or wrong was to look into our minds and consults the "inner moral light" of our conscience whose pronouncements where seen as "self-evident".

\footnotetext{
${ }^{4}$ HARE, R. M. Moral Thinking. Its Levels, Method and Point. op. cit., p. 38.

${ }^{5}$ Ibid., p. 29.

${ }^{6}$ Ibid., Chapter 6.

${ }^{7}$ KING, Peter J. The Fabric of Felicity. In: Utilitarian Jurisprudence in America: The Influence of Bentham and Austin on American Legal Thought in the $19^{\text {th }}$ Century. USA: New York, Garland Publishing Inc., 1986.
} 
Bentham, however, believed that the purpose of morality and laws was to promote the welfare of citizens and to maximize human happiness, not to enforce certain intuited unchangeable divine moral laws that label actions as bad in themselves, without regard to their consequences. Bentham also believed that his utilitarian ethical theory was implicit in what we call moral "common sense" or "intuitions" because underlying all our moral intuitions are utilitarian considerations. Hence Bentham posited the "principle of utility" defining the "good" not based on the strength of people's preferences but based on the amount of happiness or pleasures an action afforded ${ }^{8}$.

Mill too was a hedonistic utilitarian but his theory was a refinement of Bentham theory'. In Mill's view, Bentham's hedonic calculus for deciding if an act was right or wrong by subtracting the sum of all pains suffered by the individuals involved from the sum of all pleasures enjoyed by them was a gross oversimplification of "moral arithmetic"10.

\section{IDEAL UTILITARIANISM}

A third type of utilitarianism is ideal or pluralistic utilitarianism which differs from the other two in what it regards as "good". To this group of utilitarians, what constitutes "good" is not only the intrinsic value of pleasure or happiness but also other values of intrinsic worth such as the values of friendship, knowledge, love, courage, health, beauty and even certain moral qualities such as fairness. One defender of this view is G. E. Moore ${ }^{11}$. Pluralistic or ideal utilitarians believe that "goods" are good independent of any pleasure or happiness they may produce and that a world of pleasure is less valuable than a world with other forms or intrinsic value.

The next two types of utilitarianism are not discrete categories from hedonistic or ideal utilitarianism. Rather the latter two can be subsumed under each of them (act and rule utilitarianism) ${ }^{12}$.

\footnotetext{
${ }^{8}$ BENTHAM, Jeremy. Introduction. In: BURNS, J. H.; HART, H. L. A. (Ed.). Principles of Morals and Legislation.London: University of London, Athlone Press, 1970.

9 See MILL, J. S. Utilitarianism. In: ROBSON, J.M. (Ed.). Essays on Ethics, Religion and Society. Toronto: University of Toronto Press, 1969 (Collected Works of John Stuart Mill, vol. 10).

${ }^{10}$ BENTHAM, J. Op. cit., p. 88.

${ }^{11}$ MOORE, G.E. Ethics. 4.ed. Oxford: Oxford University Press, 1961, p. 138-155.

${ }^{12}$ See SMART, J. J. C. Extreme and Restricted Utilitarianism. In: SMART, J. J. C. (Ed.). Essays Metaphysical and Moral. USA: New York, Basil Blackwell Publishers Inc., p. 259-270.
} 


\section{ACT UTILITARIANISM}

Act utilitarianism is the kind of utilitarianism held by Bentham, Sidgwick and Moore. According to this doctrine, the rightness or wrongness of a particular action is to be judged by its consequences. This means that from the act utilitarian viewpoint, there can be no exception less moral rules other than the principle of utility. Thus in certain circumstances, lying, breaking promises, stealing and even killing the innocent might be the right thing to do because the consequences of doing these things might be more desirable than refraining from doing them. Bernard Williams gives one example of Jim who finds himself, while on a botanical expedition, in the central square of South American town where ten Indians, tied against a wall, are ready to be executed b y the government Soldiers as a warning for others not to stage protests against the government ${ }^{13}$. Since Jim is an honoured guest, the captain of the guard offers him a guest's privilege of killing one of the Indians himself. If Jim accepts this privilege, then the other Indians would be let off but if he does not, then all the Indians would be killed. In addition, Jim cannot conceivably rescue all the Indians at that moment without himself and all the Indians being killed by the soldiers. In such a situation, act utilitarianism would prescribe the killing of the innocent Indian as the right action.

This is not to say that the rules of conventional morality (such as "never lie", "never break promises", "never kill the innocent", etc.) are all useless. Act utilitarianism treats rules as useful rules of thumbs which, when applied in most cases would maximize happiness or produce more good than bad consequences. Rule following is also useful in emergency situations (like whether to save a drowning person or not) when there is no time to think about consequences ${ }^{14}$. But in situations in which we do have time to reflect or when we are not sure of rightness of a course of action, we should deliberate in an act utilitarian manner. Rules are not seen as absolute by the act utilitarians because complying with a rule may endanger public interest on some occasions as noted by Hume ${ }^{15}$.

\footnotetext{
${ }^{13}$ WILLIAMS, Bernard. A Critique of Utilitarianism. 24. printing. In: SMART, J.J.C.; WILLIAMS, B. (Ed.). Utilitarianism: For and Against. London: Cambridge University Press. 2005, p. 98-99.

${ }^{14}$ Ibid., p. 42-57.

${ }^{15}$ HUME, D. A Treatrise of Human Nature. L.A. Selby-Bigge (ed.), rev. by P.H. Nidditch. London: Oxford. Clarendon Press, p. 497.
} 


\section{RULE UTILITARIANISM}

Rule utilitarianism, on the other hand, holds that moral rules are more than just rules of thumbs ${ }^{16}$. It holds that the rightness or wrongness of an action is determined not by the consequences of the action on a particular occasion but by the possibility of its being subsumed under a morally acceptable rule. Whether the rule is acceptable as a moral rule depends, in turn, on the kind of consequences resulting from everybody's adoption of the rule. Thus rule utilitarianism employs the notion of "universalisation". In determining whether an act is right or wrong, one should not look at the likely consequences of an act on a particular occasion but rather at the likely consequences from the performance of the same act by everyone under the same consequences. If everyone adopts and applies the rule "I will make a promise without the intention of keeping it whenever I am hard pressed to do so", then if everyone adopts the rule, it would make nonsense of the institution of "promise-keeping"; for no one would believe anyone else. Since there are many obvious utilitarian reasons for having institution of "promise-keeping", the rule that I act on cannot be a moral one and the act based on the rule is consequently not the right act. Thus actions are to be tested by the rules which govern them which in turn are to be tested by the consequences of adopting these rules ${ }^{17}$. This is what makes the theory attractive - it resolves the dispute between intuitionists and utilitarians very neatly. The only exception where we must determine the morality of an action directly by its consequences arise when the action comes under the jurisdiction of two different rules, one prescribing and the other forbidding it (as in the case of lying to save a life) or when there is no existing rule that governs the given case ${ }^{18}$.

\section{REASONS FOR THE EVALUATION OF HARE'S PREFERENCE UTILITARIAN THEORY}

From a comparison of the various forms of utilitarianism, it becomes obvious that Hare's preference utilitarianism is superior to, and more sophisticated than, the rest. This is so because Hare's theory is a more recent

\footnotetext{
${ }^{16}$ SMART, J. J. C. Extreme and Restricted Utilitarianism. op. cit. p. 172.

${ }^{17}$ Some other rule utilitarianism theories claim that the right action is that which is based on certain actual (recognized) or ideal moral code or system of rules of a given society and it is utility that justifies decision as to whether a moral code is seen to have utility above other moral code. See BRANDT, R. Some Merit of One Form of Rule Utilitarianism. In: HARTLE, A. E.; KEKES, J. (Ed.). Dimensions of Ethical Thoughts. USA: New York. Peter Lang Publishing Inc., 1987.
}

${ }^{18}$ SMART, J. J. C. op. cit., 172. 
development and modification of the other forms of utilitarianism, being formulated with the aim of overcoming many of the traditional criticism against the other cruder forms of utilitarianism.

First, it overcomes the problems faced by hedonistic and ideal utilitarianism. It is very difficult to resolve the dispute between hedonism and idealism (in the above-mentioned context of utilitarianism) because what one considers as good (happiness, knowledge, etc.) depends a lot on one's unique personal experiences. Thus if one cannot agree on what is good, how can one try to promote good? This problem can be avoided by using the preference approach.

Secondly, by using the preference approach, Hare's theory avoids the traditional problem regarding the quantification of utility. If we take into consideration people's preferences to decides if an action is right or wrong, then we would not need to determine the quality of pleasure or distinguish between higher and lower pleasures ${ }^{19}$. Hare's preference utilitarianism allows us to measure preference utility more objectively by devising a utility scale to measure the relative strength and intensity of individual and the group preferences. This procedure is being used in voting and survey practices in which polls are taken to ascertain the preferred candidate for public office. Though he admits that exact calculations of utilities are impossible ${ }^{20}$, Hare nevertheless insists that is possible to:

1. know someone else's preferences by imagining ourselves in his shoes;

2. empathize and know to some extent other people's inner experiences (like pain, pleasure, etc.) because there is a sufficient degree of shared meaning in words - that is why we can communicate; and

3. know a person's preferences of comparative outcomes of acts by again imagining ourselves in his shoes .

In shall not, from now on, elaborate on the quantification problems in Hare's preference utilitarianism, or utilitarianism in general, for I do agree with Hare and Smart that it is indeed possible to, at least, roughly estimate the utility of an action or the preferences of the people. After all, that is what

\footnotetext{
${ }^{19}$ HARE, R. M. Moral Thinking. Its Levels, Method and Point. op. cit., p.140-146.

${ }^{20} \mathrm{G}$. E. MOORE also pointed out that a person would never have sufficient information in a concrete situation of moral choice to know that in a particular situation, breaking the rule would produce the best consequences. See MOORE, G. E. op. cit., p. 138-155.
} 
we do in our daily lives and our factual and moral reasoning. We weight the pros and cons of an action and act on it. It is what economists, politicians and entrepreneurs do and it is at least possible, to a limited extend, to know what makes others happy, what is good, what benefits others or what others would prefer (by putting ourselves in their place).

Thirdly, Hare's two levels of moral thinking "apparently" allows us to overcome many of the common intuitionist objections against utilitarianism such as the charge of rule worship, immorality, neglect of special responsibilities, duties and obligations, distributive injustice and the infringement of natural and moral rights.

\section{AN ENLIGHTENING POINT IN HARE'S TWO LEVEL OF MORAL THINKING}

Hare has made an important and illuminating distinction between two levels of moral thinking; for we indeed do our moral thinking in this way. We are conditioned, socialized or educated (sometimes consciously but most of the time unconsciously through following the way things are done around us) into believing that various acts or classes of acts are right, or wrong, just or unjust. We intuitively hold these moral judgements or principles without much reflection and are perfectly and honestly convinced that it is the right thing to do.

Thus, our intuitions are derived through education and have been tested sufficiently in the past which shows that there are good utilitarian reasons for obeying them. They tell us what the right and wrong actions are in simple moral situations ${ }^{21}$. Simple moral situations are situations involving the murder, torture and mutilation of the innocent. They are situations which involve a deep moral prohibition against the above acts of simple evil because such acts are detrimental to the attainment of the good life by the moral agent (because such acts undermine the minimum requirement of conditions necessary for the moral agent's attainment of the good life and such acts are what harm human beings always, everywhere, under all circumstances and are thus always evil.

Hare's practical syllogism allows us to recognize which moral situations are simple ones (or what Hare calls "usual cases") by stipulating that all acts

${ }^{21}$ KEKES, J. Moral Tradition and Individuality. New Jersey: Princeton. Princeton University Press, 1989, p. 90-100. 
or situations possessing the morally relevant feature mentioned in the moral situations which prescribe an action or a prohibition. For example,

$P[1]$ : All acts of murder are immoral (and we ought not to do immoral acts)

$\mathrm{P}[2]$ : Act ' $\mathrm{X}$ ' is an act of murder

On: Therefore Act ' $\mathrm{X}$ ' is immoral and we ought no to do it.

Thus is easy in simple moral situations or usual cases to recognize if an act is morally wrong or not.

However, in more complex moral situations like pre-marital or extramarital sex, homosexuality, abortion, etc., it is not so clear how useful these intuitions are. Firstly, there may be no existing moral rules telling us what to do and, secondly, our moral intuitions or judgments may conflict. In such cases, we do think critically and decide explicitly on a course of action and implicitly on a moral principle by weighing the pros and cons of each alternative and thinking critically.

\section{A CRITIQUe OF HARE'S PREFERENCE THEORY OF CRITICAL MORAL THINKING}

My agreement with Hare only goes as far as what I have mentioned. This is because one must note that thinking critically does not necessarily mean thinking in a utilitarian or preference utilitarian. Hare tells us that at the critical level, in a making a moral judgment, we must take into consideration people's preferences and desires as relevant facts to decide on what action is moral but he has produced no reason, whatsoever, for treating them as uniquely relevant ${ }^{22}$.

A defender of Hare might say that not to fulfill or satisfy people's preferences is to do evil to them but surely this is untrue since, as Bernard Williams noted, people often want, prefer or desire the wrong thing ${ }^{23}$.

Thus although I have no doubt that we often need to take into consideration the consequences of our actions on others (especially their

\footnotetext{
${ }^{22}$ HARE, R. M. Moral Thinking. Its Levels, Method and Point. op. cit., Chapters 5-6.

${ }^{23}$ WILLIAMS, Bernard. Morality: An Introduction to Ethics. USA: New York. Harper and Row Publishers Inc., 1972, p. 81.
} 
preferences and desires), that is not all we need to take into consideration. Hare does mention that there are other "facts" but he does not tell us what they are. He only goes into a detailed description of the way to evaluate people's preferences (thus implying that they are uniquely relevant). Surely "objective" moral principles (those regarding simple good and evil) which Hare denies exist at all, people's past histories, past experiences and relationships are just as relevant as considerations to be taken into account in moral judgments as consequences of actions or preferences ${ }^{24}$. (Note that these past histories, experiences, etc. are not preferences). Take, for example, the case where a person murders another innocent man in cold blood so that he can claim some insurance money. Would this not be regarded as a simple moral situation and would the action not be condemned as immoral simply on the basis of its violating an "objective" moral principle of "one ought never to murder an innocent man no matter what the circumstances?" 25 . One of the aims of morality is to minimize the amount of simple evil and this a desirable goal because it gives us the minimum condition for attaining good lives (not only for others but for ourselves too); for how can we attain good lives for ourselves in a Hobbesian state of nature? ${ }^{26}$ As I attempted do show, it is possible to identify certain situation as situations involving simple evil and hence we ought not do certain actions because they are evil. These "objective" moral principles (not in the sense of having a 'moral sense' or divine revelation but rather in the sense of being unconsciously acquired from others around us - our friend, teachers, parents, seeing how things are done, etc.) give us the reason to make certain moral judgements and "The very request for justification is a suspicious sign of gross stupidity" 27 .

${ }^{24}$ This is a point noted by P. Millican is his critical book review of Hare's book, Moral Thinking: Its levels, Method and Point, although he only mentions "objective" moral principles as another class of relevant facts to be considered at the critical level of moral thinking in making moral judgments. See MILLICAN, P. Book Review on R. M. Hare - Moral Thinking. Philosophical Quarterly. Vol. 33. N. 131, p. 210-211, April 1983. C. L. TEN also makes this point in TEN, C. L. The Utilitarian Theory. In: Crime, Guilty and Punishment. London: Oxford. Clarendon Press, p. 29.

${ }^{25}$ A fundamental issue to be settled is whether critical thinking is controlled by one principle, as Hare and other utilitarians suggest, or by an irreducible plurality of moral principle as many non-utilitarians believe.

${ }^{26}$ HOBBES, T. Leviathan. Michael Oakeshott (Ed.) London: Oxford. Basil Blackwell Publishers Inc., p. 80-84. Hobbes postulated a state of nature before society is formed whereby self-interest is the chief motivation of all man and hence there is a war of "[...] every man, against every man" (p. 83) where each man covets the possessions of the other and the fittest survive.

${ }^{27}$ See HOSPERS, J.; SELLARS, W. Readings on Ethical Theory. 2. ed. New Jersey, Englewood Cliffs: Prentice Hall Inc., 1970. 
Take another example. Imagine that one day, I find out that my sister husband is having an affair with another woman. Whether my brother-in-law's action of adultery is judged as morally right or wrong would not only depend on his and his wife's preferences but also on the number of years and the type of relationship that my sister and her husband have, the socially accepted forms of behavior, their past histories and experiences together, etc ${ }^{28}$. If her husband had always ill-treated her or had constant affairs with other women from the moment he married her, then perhaps the husband could be judge as being immoral. But if this is the first indiscretion that he has committed and he has always been very loving toward her, perhaps this is just what Hare calls a "weakness of will" or a moment of weakness. Thus her husband might not be judged as being as immoral as in the former case. If, on the other hand, his wife too has had her fair share of affairs, then I would not, so clearly, condemn his actions as wrong! My moral judgment certainly is based on more than just the husband's or wife's preferences. I has to do with what kind of relationship they have and had with each other, their past histories, etc.

What I am purporting in this paper is that morality is not a simple as Hare make it out to be. We cannot always cash out moral judgments in terms of people's preferences only because morality is not like that. In life, we often do need to make moral judgments but these judgments are not so easily determined. Many moral situations in life are like those above - "complex moral situations" where our moral intuitions may conflict or we may not have adequate moral intuitions to deal with these situations ${ }^{29}$. Hare is right in telling us that our moral intuitions are not equipped to help us deal with such situations. In these situations (particularly in moral situations involving intimate personal relationships, like the one above, which I believe form the bulk of the moral situations we encounter in life because moral situations normally occur with people we come in contact with or are close with), preferences are not the only considerations in making a moral judgement. Our past histories, experiences, other's experiences, personal relationship, the socially accepted norms of behaviors, etc, all do count in determining moral judgements in complex moral situation. Moral is like that in real life - it is a complex thing. Hare has oversimplified it.

\footnotetext{
${ }^{28}$ KEKES, J. Moral Tradition and Individuality. op. cit., p. 105-116.

${ }^{29}$ Ibid.
} 
SIMÓES, Mauro Cardoso. O utilitarismo de preferências de Hare: uma visão geral e crítica. Trans/Form/Ação, Marília, v. 36, n. 2, p. 123-134, Maio/Ago., 2013.

RESUMO: Meu propósito neste artigo é resumir alguns aspectos do utilitarismo e a visão geral do utilitarismo de preferências de Hare; em seguida, aponto uma crítica da teoria da preferência de Hare.

PALAVRAS-CHAVE: Hare. Utilitarismo. Preferências. Crítica.

\section{REFERENCES}

BENTHAM, J. Introduction. In: BURNS, H. L. A.; HART, H. L. A. (Ed.). Principles of Morals and Legislation. London: University of London, Athlone Press, 1970. BRANDT, R. Some Merit of One Form of Rule Utilitarianism. In: HARTLE, A. E.; KEKES, J. (Ed.). Dimensions of Ethical Thoughts. USA: New York: Peter Lang, 1987.

HARE, R.M. Moral Thinking. Its Levels, Method and Point. Oxford: Oxford University Press, 1981.

HUME, D. A Treatrise of Human Nature. Ed. L. A. Selby-Bigge, rev. by P. H. Nidditch. London: Oxford, Clarendon Press, 2005.

HOBBES, T. Leviathan. Ed. Michael Oakeshott. London: Oxford. Basil Blackwell, 1957. HOSPERS, J.; SELLARS, W. Readings on Ethical Theory. 2nd ed. New Jersey: Englewood Cliffs. Prentice Hall, 1970.

KEKES, J. Moral Tradition and Individuality. New Jersey-Princeton: Princeton University Press, 1989.

KING, P. J. The Fabric of Felicity. In: Utilitarian Jurisprudence in America: The Influence of Bentham and Austin on American Legal Thought in the 19th Century. USA: New York: Garland, 1986.

MILL, J. S. Utilitarianism. In: Essays on Ethics, Religion and Society. Vol. 10 of Collected Works of John Stuart Mill. Ed. J.M. Robson.Toronto: University of Toronto Press, 1969.

MILLICAN, P. Book Review on R.M. Hare - Moral Thinking. Philosophical Quarterly. Vol. 33. n. 131. April 1983.

MOORE, G. E. Ethics. 4th ed. Oxford: Oxford University Press, 1961.

SMART, J. J. C. Extreme and Restricted Utilitarianism. In: SMART, J. J. C. (Ed.). Essays Metaphysical and Moral. USA: New York, Basil Blackwell, 1987.

TEN, C. L. The Utilitarian Theory. In: Crime, Guilty and Punishment. London: Oxford, Clarendon, 1987. 
SIMÕES, M. C.

WILLIAMS, B. A Critique of Utilitarianism. In: SMART, J. J. C.; WILLIAMS, B. (Ed.). Utilitarianism: For and Against. 24th printing. London: Cambridge University Press, 2005.

WILLIAMS, B. Morality: An Introduction to Ethics. USA, New York: Harper and Row, 1972.

Recebido em: 10.11.2012

Aceito em: 09.03.2013 